\title{
Transcription Factor MafA
}

National Cancer Institute

\section{Source}

National Cancer Institute. Transcription Factor MafA. NCI Thesaurus. Code C120573.

Transcription factor MafA (353 aa, $37 \mathrm{kDa}$ ) is encoded by the human MAFA gene. This protein plays a role in the activation of insulin gene expression in the pancreas. 